\title{
Subclinical thyrotoxicosis: prevalence, causes and choice of therapy
}

\author{
Allan Carlé1, Stine Linding Andersen ${ }^{1,2}$, Kristien Boelaert ${ }^{3}$ and Peter Laurberg ${ }^{1,4}$ \\ ${ }^{1}$ Department of Endocrinology, ${ }^{2}$ Department of Clinical Biochemistry, Aalborg University Hospital, Aalborg, \\ Denmark, ${ }^{3}$ Institute of Metabolism and Systems Research, School of Medical and Dental Sciences, University of \\ Birmingham, Birmingham, UK, and ${ }^{4}$ Department of Clinical Medicine, Aalborg University, Aalborg, Denmark
}

Correspondence

should be addressed

to A Carlé

Email

carle@dadlnet.dk

\begin{abstract}
Subclinical thyrotoxicosis is a condition affecting up to $10 \%$ of the population in some studies. We have reviewed literature and identified studies describing prevalences, causes and outcomes of this condition. Treatment should be considered in all subjects if this biochemical abnormality is persistent, especially in case of symptoms of thyrotoxicosis or in the presence of any complication. In particular, treatment should be offered in those subclinically thyrotoxic patients with a sustained serum TSH below $0.1 \mathrm{U} / \mathrm{L}$. However it is important to recognise that there are no large controlled intervention studies in the field and thus there is no high quality evidence to guide treatment recommendations. In particular, there is no evidence for therapy and there is weak evidence of harm from thyrotoxicosis if serum TSH is in the $0.1-0.4 \mathrm{IU} / \mathrm{L}$ range. In this review, we describe the different causes of subclinical thyrotoxicosis, and how treatment should be tailored to the specific cause. We advocate radioactive iodine treatment to be the first-line treatment in majority of patients suffering from subclinical thyrotoxicosis due to multinodular toxic goitre and solitary toxic adenoma, but we do generally not recommend it as the first-line treatment in patients suffering from subclinical Graves' hyperthyroidism. Such patients may benefit mostly from antithyroid drug therapy. Subclinical thyrotoxicosis in early pregnancy should in general be observed, not treated. Moreover, we advocate a general restriction of therapy in cases where no specific cause for the presumed thyroid hyperactivity has been proven.
\end{abstract}

\section{Invited Authors' profiles}

Kristien Boelaert, MD, PhD, FRCP is a Reader in Endocrinology at the University of Birmingham. Her clinical research interests include the management of thyroid dysfunction, nodules and endocrine disorders in pregnancy. Her laboratory research programme focuses on the pathogenesis of thyroid cancer. Kristien is actively involved in the writing of national and international guidelines in the field of thyroid disease.

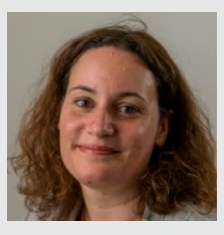

Kristien Boelaert

Allan Carlé, MD, PhD, is a senior researcher, Aalborg University Hospital, Aalborg, Denmark. His research has focused on nosological classification of various subtypes of hypothyroidism. He has explored the field of hypoand hyper-thyroidism with special focus on the occurrence in the population, biochemical findings at diagnosis, the symptom presentation across gender and age, the magnitude of avoiding referral bias in population-based studies, and he has studied several risk factors for both hyper- and hypo-thyroidism. The research frame has been DanThyr (The Danish Investigation on Iodine Intake and Thyroid Diseases).

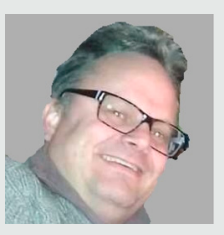

Allan Carlé www.eje-online.org DOI: 10.1530/EJE-16-0276
๑) 2017 European Society of Endocrinology Printed in Great Britain
Published by Bioscientifica Ltd. 


\section{Introduction}

Thyrotoxicosis is a common disease worldwide and may be caused by inappropriately high thyroid hormone secretion (hyperthyroidism), passive release of thyroid hormone from a damaged thyroid or from extra-thyroidal sources of excess thyroid hormone. In hyperthyroid patients, the inappropriate thyroid hyperactivity can be treated with antithyroid drugs, radioactive iodine, or surgery and optimal therapy depending on the cause and severity of the disorder. In some thyrotoxic conditions, there is a probability of disease remission with restoration of normal thyroid function. In such patients, irreversible thyroid ablation using radioactive iodine is only rarely indicated. On the other hand, some subtypes of hyperthyroidism would generally not spontaneously remit, and radioiodine therapy would often be the first choice. Current consensus guidelines from the American Thyroid Association (1) provide treatment recommendations based on the degree of TSH suppression and patients' age. This review aims to provide detailed information regarding the causes and long-term consequences of subclinical thyrotoxicosis, and to discuss the risks and benefits associated with treatment of this common condition.

In subclinical thyrotoxicosis, the serum concentrations of thyroid hormones, total T4/free $\mathrm{T} 4$ and total $\mathrm{T} 3 /$ free $\mathrm{T} 3$, are within the laboratory reference range, but TSH is abnormally low, and patients may have only few or no clinical signs of thyrotoxicosis. It is beyond the scope of the present review to enter into a detailed discussion of the various assays used to diagnose subclinical thyrotoxicosis, but extensive reviews are available elsewhere $(2,3)$. In this review, we advocate that radioactive iodine treatment may be the treatment of choice for many patients diagnosed with subclinical hyperthyroidism, at least in countries with current or recent low iodine intake, where many elderly people suffer from the consequences of previous iodine deficiency. On the other hand, patients suffering from Graves' disease with only subclinical hyperthyroidism may often enter remission during a course of antithyroid drug therapy.

\section{Subclinical thyrotoxicosis and its nosological types}

Since early 1970s, the entity of subclinical hypothyroidism with isolated elevated serum TSH concentration was defined (4), and in the mid-1980s new TSH assays with a sensitivity of $0.1 \mathrm{U} / \mathrm{L}$ (5) made it possible to identify subnormal serum TSH concentrations. Thus, a new group of patients was identified with a low serum TSH but with $\mathrm{T} 4$ and $\mathrm{T} 3$ within the laboratory reference ranges. The new term 'subclinical' thyrotoxicosis is rather misleading as the diagnosis is based solely on biochemical testing and not on the presence or absence of any symptom (5). In the ATA/AACE thyrotoxicosis treatment guidelines by Bahn et al. (6) and the recent European Guidelines by Biondi et al. (7) it is proposed that clinical outcomes may depend on the degree of TSH suppression, and the physician should distinguish between patients with TSH lower than $0.1 \mathrm{U} / \mathrm{L}$ and those with only mildly suppressed TSH between 0.1 and the lower assay reference limit.

However, only a proportion of the thyrotoxic patients fulfilling the above criteria suffer from endogenous subclinical hyperthyroidism, and other causes should be ruled out such as exogenous thyroid hormone use, the consumption of other TSH-suppressing drugs (e.g. dopamine or glucocorticoids), non-thyroidal illness (low T3 syndrome), low serum TSH during first trimester of pregnancy, pituitary and hypothalamic insufficiency, or falsely undetectable TSH caused by assay problem (8). The TSH reference range broadens with age and there is mounting evidence for increased upper limits (9) as well as decreased lower limits $(10,11)$. As a general rule, therapy should only be given when the cause for mild hyperthyroidism has been revealed. To focus more on the disorder than on the biochemistry, it has been suggested to abandon the term 'subclinical' (12).

Depending on the study population, subclinical thyrotoxicosis may be very common. Most studies reported a low TSH to be present in approximately $1-5 \%$ of the investigated people (Table 1, $(13,14,15,16,17,18$, $19,20,21,22,23,24,25,26,27,28,29,30,31,32,33$, $34,35,36,37,38,39,40,41,42,43,44))$. Some of these studies documented normal serum T4 concentrations; others did only measure serum TSH. Some of the studies provided prevalences on subclinical thyrotoxicosis in terms of different serum TSH cut-off values $(13,14,16,20$, $32,36,43,45)$ and showed that most cases of subclinical thyrotoxicosis presented with serum TSH above $0.1 \mathrm{U} / \mathrm{L}$. Thus, up to eight-fold lower prevalence of subclinical thyrotoxicosis was found if the serum TSH cut-off was changed from the lower laboratory reference value of 0.3 $0.4 \mathrm{U} / \mathrm{L}$ and down to $0.1 \mathrm{U} / \mathrm{L}$. The prevalence is as may be anticipated, fundamentally dependent on the TSH threshold chosen. Another limitation is that the methods used and the cohorts investigated in the studies listed in Table 1 are heterogeneous. 
Table 1 Prevalence of suppressed serum TSH concentrations in various populations in order of frequency.

\begin{tabular}{|c|}
\hline First author \\
\hline Völzke $(13) * / * *$ \\
\hline Sawin $(14) * / * *$ \\
\hline Muller (15) \\
\hline Parle $(16) * / * *$ \\
\hline Seck (17) \\
\hline Aghini-Lombardi (18)* \\
\hline Sgarbi (19)* \\
\hline Parle $(20) * *$ \\
\hline Knudsen $(21) *$ \\
\hline Manciet $(22) * *$ \\
\hline Eggertsen (23)* \\
\hline Gussekloo (24) \\
\hline Sowers (25) \\
\hline Delitala (26)* \\
\hline Teng (27) \\
\hline Bagchi (28) \\
\hline Gamage (29)* \\
\hline Wilson $(30)^{*}$ \\
\hline Völzke (13)*/** \\
\hline Sawin $(31)^{*}$ \\
\hline Bjorndal $(32) * / * *$ \\
\hline Knudsen (33)* \\
\hline Boekholdt (34) \\
\hline Manciet $(22)^{* *}$ \\
\hline Sundbeck (35)* \\
\hline Hollowell (36)*/** \\
\hline Selmer (37)* \\
\hline Parle $(16) * / * *$ \\
\hline Cappola (38)* \\
\hline Brochmann (39) \\
\hline Parle $(20) * *$ \\
\hline Sawin $(14) * / * *$ \\
\hline Nanchen (40) \\
\hline Meyerovitch (41)* \\
\hline Canaris $(42) *$ \\
\hline Bjoro $(43) * / * *$ \\
\hline Konno $(44) *$ \\
\hline Bjorndal $(32) * / * *$ \\
\hline Hollowell $(36) * / * *$ \\
\hline Bjoro $(43) * / * *$ \\
\hline Bjorndal $(32) * / * *$ \\
\hline
\end{tabular}

\begin{tabular}{|c|c|}
\hline Year & Country \\
\hline 2003 & Germany \\
\hline 1994 & US \\
\hline 1997 & South Africa \\
\hline 2001 & UK \\
\hline 1997 & Germany \\
\hline 1999 & Italy \\
\hline 2010 & Brazil + Japan \\
\hline 1991 & UK \\
\hline 2000 & Denmark \\
\hline 1995 & France \\
\hline 1988 & Sweden \\
\hline 2004 & Netherlands \\
\hline 2003 & US \\
\hline 2014 & Italy \\
\hline 2011 & China \\
\hline 1990 & US \\
\hline 2007 & UK \\
\hline 2006 & UK \\
\hline 2003 & Germany \\
\hline 1991 & UK \\
\hline 2008 & Norway \\
\hline 1999 & Denmark \\
\hline 2010 & UK \\
\hline 1995 & France \\
\hline 1991 & Sweden \\
\hline 2002 & US \\
\hline 2012 & DK \\
\hline 2001 & UK \\
\hline 2006 & US \\
\hline 1988 & Norway \\
\hline 1991 & UK \\
\hline 1994 & UK \\
\hline 2012 & Netherlands + Scotland + Ireland \\
\hline 2007 & Israel \\
\hline 2000 & US \\
\hline 2000 & Norway \\
\hline 1993 & Japan \\
\hline 2008 & Norway \\
\hline 2002 & US \\
\hline 2000 & Norway \\
\hline 2008 & Norway \\
\hline
\end{tabular}

\begin{tabular}{ccc}
\hline Prevalence of low serum TSH $(\%)$ & Serum TSH lower cut-off $(\mathrm{U} / \mathrm{L})$ \\
\cline { 1 - 1 } 11.3 & 0.3 \\
10.2 & 0.4 \\
9.4 & 0.4 \\
7.6 & 0.5 \\
6.6 & 0.3 \\
6.4 & 0.4 \\
6.2 & 0.45
\end{tabular}

6.2

0.45

$5.9-0.5$

$4.9-0.4$

$\begin{array}{ll}4.2 & 0.4\end{array}$

$3.5-0.2$

$3.4-0.3$

3.20 .5

$2.8-0.4$

$2.7 \quad 0.3$

$\begin{array}{ll}2.7 & 0.1\end{array}$

$2.4 \quad 0.4$

$2.4 \quad 0.4$

$2.2 \quad 0.1$

$2.1 \quad 0.3$

$2.1 \quad 0.5$

$\begin{array}{ll}2.0 & 0.15\end{array}$

1.9 0.4

$1.9 \quad 0.2$

$\begin{array}{ll}1.9 & 0.2\end{array}$

$1.8 \quad 0.4$

$\begin{array}{ll}1.8 & 0.2\end{array}$

$\begin{array}{ll}1.7 & 0.1\end{array}$

$\begin{array}{ll}1.6 & 0.44\end{array}$

$\begin{array}{ll}1.5 & 0.1\end{array}$

$\begin{array}{ll}1.4 & 0.05\end{array}$

$\begin{array}{ll}1.3 & 0.1\end{array}$

$1.3 \quad 0.45$

1.20 .35

$\begin{array}{ll}1.0 & 0.3\end{array}$

$0.6 \quad 0.2$

$0.6 \quad 0.15$

$0.44 \quad 0.2$

$0.4 \quad 0.1$

$0.34 \quad 0.05$

$0.24 \quad 0.05$

*Studies that provided prevalence data or from which we calculated the prevalence of low serum TSH among subjects with no thyroid disease. ** Some studies gave several prevalences of low TSH according to different serum TSH cut-off levels $(13,14,16,20,32,36,43)$.

A comprehensive list of possible causes of endogenous subclinical thyrotoxicosis was published by Cooper and Biondi (46). In different populations, the relative distribution of the various nosological types of thyrotoxicosis may differ substantially in both overt and subclinical thyrotoxicosis. Most studies on the prevalence of thyrotoxicosis did not take into account that the disease entity is comprised by several different subtypes. Similarly, most incidence rates have only focused on a few entities within the thyrotoxic spectrum. Thus, knowledge of the distribution of various subtypes of thyrotoxicosis mostly relies on studies of overt thyrotoxicosis. Graves' disease and toxic nodular disease are by far the most common causes (47), and the balance between these two entities is largely dependent on the iodine intake of the population $(48,49)$. Implementation of iodine fortification also has large impact on the occurrence of thyrotoxicosis $(50,51)$.

Graves' disease is the dominating cause of overt thyrotoxicosis in iodine-replete countries such as Iceland (52), whereas toxic multinodular goitre may be as common as Graves' disease in countries with mild-tomoderate iodine deficiency (47). The thyroid autonomy developing after a long period of low iodine intake may not disappear after an increase in iodine intake 
('iodine memory' (48)) and toxic multinodular goitre may also be common among elderly people living in areas with iodine intake that is currently sufficient, but was previously deficient. Also, people who emigrated from areas with low iodine intake to areas with sufficient iodine intake may have high prevalence of thyroid autonomy. Because overt hyperthyroidism caused by nodular autonomy may develop gradually over years, whereas Graves' hyperthyroidism based on current knowledge tend to develop more rapidly, nodular autonomy is rather common in subclinical thyrotoxicosis.

Two Danish studies $(21,52)$ combined with data from a study recently published (53) depict the causal importance of iodine intake on the occurrence of subclinical thyrotoxicosis (Fig. 1, (21, 52, 53)). While subclinical thyrotoxicosis was rare in iodine-excess Iceland subjects aged approximately 70 years, $2-4 \%$ of the elderly population residing in moderate-to-mild iodine-deficient Danish areas had a serum TSH $<0.1 \mathrm{U} / \mathrm{L}$. Furthermore, $8-10 \%$ of the Danish women and $4-6 \%$ of the men had a

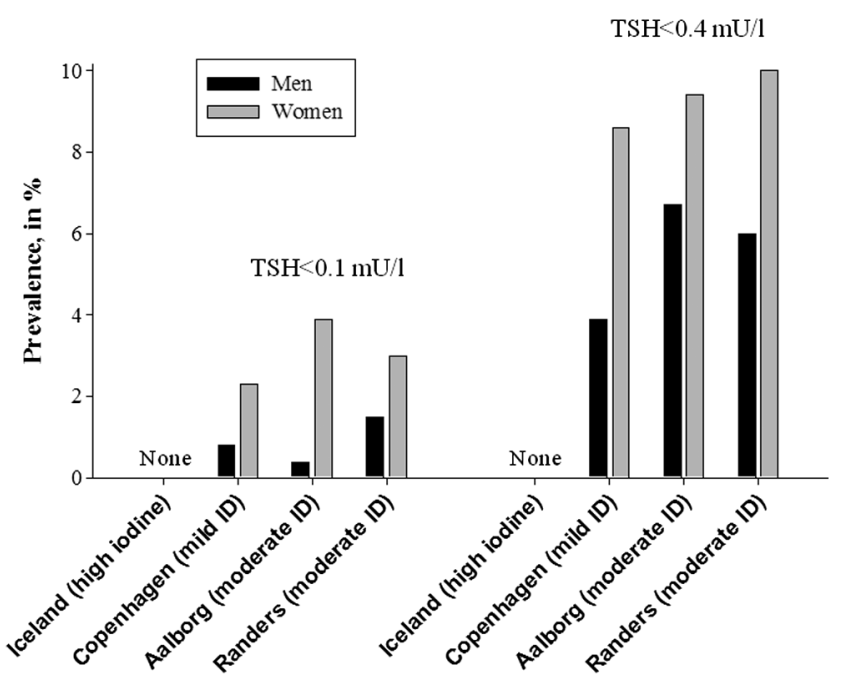

Regions according to iodine intake level

\section{Figure 1}

The prevalence of low serum TSH $(<0.1 \mathrm{U} / \mathrm{L}$ on the left; $<0.4 \mathrm{U} / \mathrm{L}$ on the right) in Danish and Icelandic populationbased studies performed in areas with different iodine intake levels: Iceland (high iodine intake, age 66-70 years, $n=100$ (52)); Copenhagen, Denmark (mild iodine deficiency, 60-75 years, $n=937(21,53)$ ); Aalborg, Denmark (moderate iodine deficiency, 60-75 years, $n=935(21,53)$ ); Randers, Denmark (moderate iodine deficiency, 68-year-old citizens, $n=423$ (52)). In all populations, subjects previously diagnosed with biochemical thyroid disease were excluded. serum TSH $<0.4 \mathrm{U} / \mathrm{L}$. Results are corroborated by a recent Dutch study (54) on serum TSH and fT4 in laboratory databases. In the historically iodine-deficient parts of the Netherlands, a negative correlation between age and serum TSH was observed, presumably because the thyroid gland of many older people harboured autonomously functioning nodules.

The overall risk for being diagnosed with a certain subtype of thyrotoxicosis depends on a number of factors such as gender $(21,28,33,36,43)$, age $(18,21,26,33,42$, $43)$, ethnicity $(25,28,36)$ and smoking $(55,56)$. A few studies have classified subclinical thyrotoxicosis according to the cause of disease $(32,44,57,58)$. According to those studies, Graves' disease was the cause of subclinical thyrotoxicosis in $15 \%$ of patients in iodine-sufficient but previously iodine-deficient Norway. In iodine-abundant Japan (44) approximately $64 \%$ of all subclinically thyrotoxic cases could be attributed to Graves' disease.

Within the spectrum of subclinical thyrotoxicosis, complete suppression of serum TSH is associated with higher risks of suffering from Graves' disease compared to the other subtypes of thyrotoxicosis. This was shown by Bjorndal et al. (32), who found that Graves' disease was the cause in $40 \%$ of severely subclinically thyrotoxic patients (serum $\mathrm{TSH}<0.05 \mathrm{U} / \mathrm{L}$ ) but it was the cause for only $15 \%$ of those with mild subclinical thyrotoxicosis (serum TSH between 0.05 and $0.49 \mathrm{U} / \mathrm{L}$ ). Rosario (57) also found that Graves' disease was a rather uncommon cause (7\% compared to 93\% due to nodular autonomy) among those with a serum TSH between 0.1 and $0.4 \mathrm{U} / \mathrm{L}$.

\section{Consequences of 'wait and see'}

The clinical significance of subclinical thyrotoxicosis has been extensively reviewed by Biondi et al. (7). Sustained subclinical thyrotoxicosis is associated with a broad spectrum of physiological changes, of which some are at least partly reversible. However, one must remember that many patients with isolated low serum TSH may have their thyroid function normalised without treatment and that therapy should never be based on single biochemical testing of thyroid function. Rosario et al. (57) reported that $13 \%$ of subjects having subclinical thyrotoxicosis by a single thyroid function testing had experienced spontaneous normalisation of thyroid function tests within 3 months, and within a 12-month period serum TSH normalised spontaneously in 38 out of 50 patients in a study by Parle et al. (20).

On the other hand, subclinical thyrotoxicosis may progress to overt thyrotoxicosis. The rate of progression 
It is beyond the scope of the present review to also contemplate on the association between subclinical hyperthyroidism and depression, dementia and physical performance.

In conclusion, evidence for treating subclinical thyrotoxicosis arises from epidemiological studies of community-dwelling individuals who had a single estimation of thyroid function and not from those with persistent endogenous subclinical hyperthyroidism referred to endocrinologists. Nonetheless, current guidelines for treatment (1) are based on the associations between mild hyperthyroidism and deleterious consequences for the cardiovascular system, the skeleton, mood and cognition as well as increased mortality. Importantly, the evidence for recommending treatment is not based on large high-quality randomised controlled intervention trails and further studies are required.

\section{Individual therapy based on the cause of subclinical thyrotoxicosis}

The possible regimes for treating subclinical thyrotoxicosis consist of antithyroid medication, radioactive iodine and thyroid surgery. The choice of treatment in the individual patient depends on a number of factors of which the specific subtype of subclinical thyrotoxicosis and the patient's preference are the most important. In general, surgical therapy is only considered in specific situations such as a solitary hot nodule, suspicion of a malignant nodule, compressive symptoms from a goitre, failure of radioiodine treatment or intolerance to antithyroid drugs (90). Before considering any treatment, the physician must ensure that the patient has sustained biochemical subclinical thyrotoxicosis by a confirmatory thyroid function testing performed several months later. Moreover, it is mandatory to diagnose the cause of the disease. Patients having suppressed TSH in early pregnancy should not be treated for thyrotoxicosis. Due to low thyroidal iodine uptake, radioactive iodine treatment has no role in treatment of patients with excess iodine intake. Neither antithyroid medicine nor radioiodine should be used in patients suffering from one of the various forms of thyroiditis as they may cause disruption of the thyroid tissue integrity. As the inflammation causing the damaged thyroid tissue is a temporal phenomenon in nearly all cases, no specific treatment is required.

Patients with subclinical hyperthyroidism caused by Graves' disease would most often have mild autoimmune abnormalities that may even enter remission spontaneously during the beta-blocker therapy (91), or enter lasting remission if given antithyroid drug therapy (92). TSH-receptor antibodies (TRAbs) are detectable in most patients with Graves' hyperthyroidism, but subsets of those with very mild disease are TRAb negative (93). A thyroid gland with a diffuse thyroidal Tc-scintigraphy uptake despite suppressed serum TSH would most often be diagnostic for Graves' disease in a hyperthyroid patient. Some other but rare causes are hCG producing molar, choriocarcinoma or germinoma (94), and genomic TSH receptor mutation. We only advocate radioactive iodine in patients with subclinical Graves' hyperthyroidism in specific situations such as intolerance to antithyroid drug therapy or symptoms from a large goitre.

The use of radioiodine treatment in benign thyroid disease has been extensively debated in a review by Bonnema and Hegedüs (95). In patients with very large goitres extending into the intrathoracic compartment, a hyperthyroid state may well be treated with radioactive

Table 3 Causes of subclinical thyrotoxicosis (our preferred treatment is provided in italics). This table only includes biochemical subclinical thyrotoxicosis having the causes listed above, and not biochemical aberrations caused by other diseases and drugs as discussed elsewhere.

Autonomous thyroid hormone secretion

Multinodular autonomous goitre (radioactive iodine)

Solitary hyperfunctioning adenoma (radioactive iodine)

Genomic constitutive activating TSH-receptor mutation (surgery) (101)

Excessive TSH-receptor stimulation

Graves' disease (antithyroid medication)

Gestational transient thyrotoxicosis (wait and see)

hCG-producing molar or choriocarcinoma (surgery)

Familial gestational thyrotoxicosis (antithyroid medication) (102)

TSH-producing pituitary adenoma (surgery)

Follicle destruction with thyroid hormone release (all wait and see)

Subacute granulomatous 'de Quervains' thyroiditis

Painless (silent) thyroiditis

Acute suppurative thyroiditis

Manipulation thyroiditis

latrogenic thyroiditis due to immunotherapy or other drugs

Extrathyroidal sources of thyroid hormone

latrogenic overreplacement with thyroid hormone (adjust L-T4 doses)

Self-administered thyroid medication (stop treatment) Food and supplements with thyroid hormone (stop intake) Functional thyroid cancer metastases (radioactive iodine)

TSH suppressive therapy with steroids or dopamine (none)

Struma ovarii (surgery)

Other

TSH assay artefact (none)

Old age 
Table 4 Advantages of various therapy regimes in subclinical hyperthyroidism.

(a) Radioactive iodine (RI) therapy in nodular hyperthyroidism

- Low risk of permanent hypothyroidism following RI treatment (10-20\% compared to 80-100\% in Graves' hyperthyroidism)

- Decrease in thyroid volume of around $50 \%$

- Often requires only single administration

(b) Antithyroid drug therapy in Graves' disease

- Low dose of drug associated with less side effects

- High likelihood of remission of autoimmune abnormality

- Good probability of returning to 'life without medication'

iodine despite the risk of inducing hypothyroidism (96). The thyroid size may decrease with 30-60\% $(96,97,98$, 99 , 100). Furthermore, any compressive effect of the goitre affecting the inspiratory phase of the respiration may benefit from radioactive iodine treatment (96). Table $3((101,102))$ shows the main causes for subclinical thyrotoxicosis and how we propose to address them. The central indication for the use of radioactive iodine therapy in subclinical hyperthyroidism is disease caused by a solitary or by multiple autonomously functioning thyroid nodules (Table 4). These two entities are very common causes of both overt and subclinical hyperthyroidism in countries with current (47) or previously low iodine intake (103). If radioactive iodine is given to patients without pretreatment with antithyroid drugs, the preferential uptake of 131-iodine in the hyperactive nodules may to some degree spare the surrounding normal thyroid tissue, and patients may become euthyroid with no need to take medication. This was shown by Faber et al. (104), who reported that 16 women with nodular goitre and subclinical thyrotoxicosis who underwent radioactive iodine treatment became euthyroid within 2 years compared to no normalisation in any of the 12 patients who were not treated. Moreover, the beneficial effects of such therapy were demonstrated; 2 years following the study start those in the treated and now biochemically euthyroid group had higher spine and hip BMD compared to non-treated subjects who were still subclinically hyperthyroid. The positive effects on serum TSH and BMD were similar in the study of Rosario et al. (105), who included both patients with subclinical hyperthyroidism due to uninodularity and multinodularity and found that $83 \%$ had normalisation of thyroid function within a year after radioiodine treatment. Effects of treatment in patients diagnosed with multinodular goitre and subclinical hyperthyroidism have been shown including partial normalisation of heart rate (106), cardiac output (106) and systemic vascular resistance (106).

\section{Side effects of subclinical hyperthyroidism therapy}

A few potential side effects of radioactive iodine treatment should be mentioned. The risk of iatrogenic hypothyroidism following radioiodine therapy is higher in Graves' hyperthyroidism compared to treatment of subclinical hyperthyroidism caused by thyroid autonomy.

No data are available on the risk for development of hypothyroidism after radioiodine therapy of subclinical thyrotoxicosis caused by autonomy. However, the risk for iatrogenic thyroid failure following radioiodine therapy in overt thyrotoxicosis caused by autonomy is approximately 5\% after 1 year (107, 108, 99, 109), 15\% after 5 years (109), and more than 60\% after 20 years (107, 108) depending on the doses administered. The highest risk has been observed in patients whose serum TSH due to antithyroid pretreatment was no more suppressed (110).

Approximately 5\% of patients treated for autonomous hyperthyroidism may develop thyroid hormone receptor antibodies (TRAb) in the months and the first year after the treatment (111). In addition, Graves' patients may experience enhancement of serum TRAb levels and worsening of eye symptoms. In the weeks following radioactive iodine treatment, the thyroid tissue may become inflammed, and thyroid volume expansion of approximately $10 \%$ and transient overt thyrotoxicosis may emerge.

Several long-term follow-up studies have indicated increased mortality $(112,113,114,115,116)$ in overtly thyrotoxic patients who have previously undergone radioactive iodine treatment, but no study has evaluated survival in patients with subclinical thyrotoxicosis after such therapy. The current ATA/ACEE guidelines on hyperthyroidism include a table on estimated risk of incidence of cancer mortality after radioiodine therapy (117). The hypothetical lifetime risk of cancer after $15 \mathrm{mC}$ (555 MBq) 131 -I is $9.9 \%$ in a 1 -year old, 
$4 \%$ in a 5 -year old, $0.8 \%$ in a 20 -year old and $0.46 \%$ in a 60 -year old, all on top of a background risk of $25 \%$. Thus, radioiodine therapy should preferably be used in older patients.

The adverse effects to antithyroid medication of subclinical hyperthyroidism are those also observed during therapy of overt hyperthyroidism (118). Approximately $5 \%$ of patients may experience minor (119), mostly cutaneous adverse effects to the drugs, and very few will have severe adverse effects. Most adverse effects to antithyroid drugs seem to be dose-dependent (118), and the low doses of methimazole (approximately $5 \mathrm{mg}$ per day) used to treat subclinical hyperthyroidism caused by Graves' disease are unlikely to have many side effects. No study gives exact information on the frequency of side effects when low-dose antithyroid drugs are used to treat subclinical hyperthyroidism. In large studies, the risk of agranulocytosis from methimazole use (all doses) was approximately $0.1-0.3 \%(120,121,122)$ and liver failure was less common (122). Such side effects mostly develop during the initial months of the therapy (120, $121,122)$.

A special situation is the therapy of subclinical hyperthyroidism in women who may become pregnant, and women who are pregnant. Antithyroid drugs may be teratogenic with the highest risk (birth defects in $1 / 30$ exposed to methimazole $(123,124), 1 / 40$ exposed to propylthiouracil $(124,125))$ in weeks six to ten of pregnancy (126). Thus, women who are treated with antithyroid drugs for subclinical hyperthyroidism and who may potentially become pregnant should be instructed to test for pregnancy very early (the first week of a missing or unusually weak menstruation), to stop the medication if the test is positive, and to immediately contact the physician responsible for the therapy to plan further management (127). Women whose biochemical test results indicate subclinical hyperthyroidism in the first trimester of pregnancy should not be treated with antithyroid drugs, but the condition should be observed with thyroid testing every 1-3 weeks taking into account the early pregnancy variation in results of thyroid function tests (128). In a large study performed in the US, subclinical hyperthyroidism in early pregnancy was not associated with any pregnancy complication (129).

If surgery is performed in a patient with subclinical hyperthyroidism, the post-surgery complications are those also experienced following thyroid surgery for overt thyrotoxicosis (130).

\section{Conclusion}

Subclinical thyrotoxicosis is a condition affecting up to $10 \%$ of the population depending on the TSH cut-off value for defining the condition and the iodine intake of the population. Many cases of subclinical hyperthyroidism would have been prevented by sufficient iodine intake. Treatment should be considered in all subjects with symptoms of thyrotoxicosis or other complications to the abnormalities, and especially in those with a sustained serum TSH below $0.1 \mathrm{U} / \mathrm{L}$. Treatment should be tailored to the specific cause of subclinical thyrotoxicosis. We advocate radioactive iodine treatment to be first-line consideration in subclinical thyrotoxicosis due to nodular autonomy (multinodular toxic goitre and solitary adenoma). On the other hand, we do recommend antithyroid drugs as the first-line treatment in the group of patients suffering from subclinical hyperthyroidism caused by Graves' disease. Special precautions are necessary when using antithyroid drug therapy for subclinical hyperthyroidism in women who may in the future become pregnant, or who are already pregnant.

\section{Declaration of interest}

The authors declare that there is no conflict of interest that could be perceived as prejudicing the impartiality of the research reported.

\section{Funding}

This research did not receive any specific grant from any funding agency in the public, commercial or not-for-profit sector.

\section{References}

1 Ross DS, Burch HB, Cooper DS, Greenlee MC, Laurberg P, Maia AL, Rivkees SA, Samuels M, Sosa JA, Stan MN et al. 2016 American thyroid association guidelines for diagnosis and management of hyperthyroidism and other causes of thyrotoxicosis. Thyroid 2016 26 1343-1421. (doi:10.1089/thy.2016.0229)

2 Baloch Z, Carayon P, Conte-Devolx B, Demers LM, FeldtRasmussen U, Henry JF, LiVosli VA, Niccoli-Sire P, John R, Ruf $\mathrm{J}$ et al. Laboratory medicine practice guidelines. Laboratory support for the diagnosis and monitoring of thyroid disease. Thyroid 200313 3-126. (doi:10.1089/105072503321086962)

3 Stockigt J. Assessment of thyroid function: towards an integrated laboratory - clinical approach. Clinical Biochemist Reviews 200324 109-122.

4 Evered DC, Ormston BJ, Smith PA, Hall R \& Bird T. Grades of hypothyroidism. British Medical Journal 19731 657-662. (doi:10.1136/bmj.1.5854.657)

5 Cooper DS. Subclinical thyroid disease: consensus or conundrum? Clinical Endocrinology 200460 410-412. (doi:10.1111/j.13652265.2004.02031.x)

6 Bahn Chair RS, Burch HB, Cooper DS, Garber JR, Greenlee MC, Klein I, Laurberg P, McDougall IR, Montori VM, Rivkees SA et al. 
Hyperthyroidism and other causes of thyrotoxicosis: management guidelines of the American Thyroid Association and American Association of Clinical Endocrinologists. Thyroid 201121 593-646. (doi:10.1089/thy.2010.0417)

7 Biondi B, Bartalena L, Cooper DS, Hegedus L, Laurberg P \& Kahaly GJ. The 2015 European thyroid association guidelines on diagnosis and treatment of endogenous subclinical hyperthyroidism. European Thyroid Journal 20154 149-163. (doi:10.1159/000438750)

8 Drees JC, Stone JA, Reamer CR, Arboleda VE, Huang K, Hrynkow J, Greene DN, Petrie MS, Hoke C, Lorey TS et al. Falsely undetectable TSH in a cohort of South Asian euthyroid patients. Journal of Clinical Endocrinology and Metabolism 201499 1171-1179. (doi:10.1210/jc.2013-2092)

9 Surks MI \& Hollowell JG. Age-specific distribution of serum thyrotropin and antithyroid antibodies in the u.s. population: implications for the prevalence of subclinical hypothyroidism. Journal of Clinical Endocrinology and Metabolism 200792 45754582. (doi:10.1210/jc.2007-1499)

10 Mariotti S, Barbesino G, Caturegli P, Bartalena L, Sansoni P, Fagnoni F, Monti D, Fagiolo U, Franceschi C \& Pinchera A. Complex alteration of thyroid function in healthy centenarians. Journal of Clinical Endocrinology and Metabolism 199377 11301134. (doi:10.1210/jc.77.5.1130)

11 Magri F, Muzzoni B, Cravello L, Fioravanti M, Busconi L, Camozzi D, Vignati G \& Ferrari E. Thyroid function in physiological aging and in centenarians: possible relationships with some nutritional markers. Metabolism 200251 105-109. (doi:10.1053/ meta.2002.28968

12 Wiersinga WM. Guidance in subclinical hyperthyroidism and subclinical hypothyroidism: are we making progress? European Thyroid Journal 20154 143-148. (doi:10.1159/000438909)

13 Volzke H, Ludemann J, Robinson DM, Spieker KW, Schwahn C, Kramer A, John U \& Meng W. The prevalence of undiagnosed thyroid disorders in a previously iodine-deficient area. Thyroid 200313 803-810. (doi:10.1089/105072503768499680)

14 Sawin CT, Geller A, Wolf PA, Belanger AJ, Baker E, Bacharach P, Wilson PW, Benjamin EJ \& D'Agostino RB. Low serum thyrotropin concentrations as a risk factor for atrial fibrillation in older persons. New England Journal of Medicine 1994331 1249-1252. (doi:10.1056/NEJM199411103311901)

15 Muller GM, Levitt NS \& Louw SJ. Thyroid dysfunction in the elderly. South African Medical Journal 199787 1119-1123.

16 Parle JV, Maisonneuve P, Sheppard MC, Boyle P \& Franklyn JA. Prediction of all-cause and cardiovascular mortality in elderly people from one low serum thyrotropin result: a 10-year cohort study. Lancet 2001358 861-865. (doi:10.1016/S01406736(01)06067-6)

17 Seck T, Scheidt-Nave C, Ziegler R \& Pfeilschifter J. Prevalence of thyroid gland dysfunctions in 50- to 80-year-old patients. An epidemiologic cross-sectional study in a southwestern community. Medizinische Klinik 199792 642-646. (doi:10.1007/ BF03044819)

18 Aghini-Lombardi F, Antonangeli L, Martino E, Vitti P, Maccherini D, Leoli F, Rago T, Grasso L, Valeriano R, Balestrieri A et al. The spectrum of thyroid disorders in an iodine-deficient community: the Pescopagano survey. Journal of Clinical Endocrinology and Metabolism 199984 561-566. (doi:10.1210/jc.84.2.561)

19 Sgarbi JA, Matsumura LK, Kasamatsu TS, Ferreira SR \& Maciel RM. Subclinical thyroid dysfunctions are independent risk factors for mortality in a 7.5-year follow-up: the Japanese-Brazilian thyroid study. European Journal of Endocrinology 2010162 569-577. (doi:10.1530/EJE-09-0845)

20 Parle JV, Franklyn JA, Cross KW, Jones SC \& Sheppard MC. Prevalence and follow-up of abnormal thyrotrophin (TSH) concentrations in the elderly in the United Kingdom. Clinical
Endocrinology 199134 77-83. (doi:10.1111/j.1365-2265.1991. tb01739.x)

21 Knudsen N, Bulow I, Jorgensen T, Laurberg P, Ovesen L \& Perrild $\mathrm{H}$. Comparative study of thyroid function and types of thyroid dysfunction in two areas in Denmark with slightly different iodine status. European Journal of Endocrinology 2000143 485-491. (doi:10.1530/eje.0.1430485)

22 Manciet G, Dartigues JF, Decamps A, Barberger-Gateau P, Letenneur L, Latapie MJ \& Latapie JL. The PAQUID survey and correlates of subclinical hypothyroidism in elderly community residents in the southwest of France. Age Ageing 199524 235-241. (doi:10.1093/ageing/24.3.235)

23 Eggertsen R, Petersen K, Lundberg PA, Nystrom E \& Lindstedt G. Screening for thyroid disease in a primary care unit with a thyroid stimulating hormone assay with a low detection limit. BMJ 1988 297 1586-1592. (doi:10.1136/bmj.297.6663.1586)

24 Gussekloo J, van Exel E, de Craen AJ, Meinders AE, Frolich M \& Westendorp RG. Thyroid status, disability and cognitive function, and survival in old age. JAMA 2004292 2591-2599. (doi:10.1001/ jama.292.21.2591)

25 Sowers M, Luborsky J, Perdue C, Araujo KL, Goldman MB \& Harlow SD. Thyroid stimulating hormone (TSH) concentrations and menopausal status in women at the mid-life: SWAN. Clinical Endocrinology 200358 340-347. (doi:10.1046/j.13652265.2003.01718.x)

26 Delitala AP, Pilia MG, Ferreli L, Loi F, Curreli N, Balaci L, Schlessinger D \& Cucca F. Prevalence of unknown thyroid disorders in a Sardinian cohort. European Journal of Endocrinology 2014171 143-149. (doi:10.1530/EJE-14-0182)

27 Teng X, Shan Z, Chen Y, Lai Y, Yu J, Shan L, Bai X, Li Y, Li N, Li $\mathrm{Z}$ et al. More than adequate iodine intake may increase subclinical hypothyroidism and autoimmune thyroiditis: a cross-sectional study based on two Chinese communities with different iodine intake levels. European Journal of Endocrinology 2011164 943-950. (doi:10.1530/eje-10-1041)

28 Bagchi N, Brown TR \& Parish RF. Thyroid dysfunction in adults over age 55 years. A study in an urban US community. Archives of Internal Medicine 1990150 785-787. (doi:10.1001/archi nte.1990.00390160053012)

29 Gammage MD, Parle JV, Holder RL, Roberts LM, Hobbs FD, Wilson S, Sheppard MC \& Franklyn JA. Association between serum free thyroxine concentration and atrial fibrillation. Archives of Internal Medicine 2007167 928-934. (doi:10.1001/ archinte.167.9.928)

30 Wilson S, Parle JV, Roberts LM, Roalfe AK, Hobbs FD, Clark P, Sheppard MC, Gammage MD, Pattison HM \& Franklyn JA. Prevalence of subclinical thyroid dysfunction and its relation to socioeconomic deprivation in the elderly: a communitybased cross-sectional survey. Journal of Clinical Endocrinology and Metabolism 200691 4809-4816. (doi:10.1210/jc.2006-1557)

31 Sawin CT, Geller A, Kaplan MM, Bacharach P, Wilson PW \& Hershman JM. Low serum thyrotropin (thyroid-stimulating hormone) in older persons without hyperthyroidism. Archives of Internal Medicine 1991151 165-168. (doi:10.1001/archi nte.1991.00400010159025)

32 Bjorndal MM, Sandmo WK, Lu T \& Jorde R. Prevalence and causes of undiagnosed hyperthyroidismin an adult healthy population. The Tromso study. Journal of Endocrinological Investigation $2008 \mathbf{3 1}$ 856-860. (doi:10.1007/BF03346431)

33 Knudsen N, Jorgensen T, Rasmussen S, Christiansen E \& Perrild $\mathrm{H}$. The prevalence of thyroid dysfunction in a population with borderline iodine deficiency. Clinical Endocrinology 199951 361-367. (doi:10.1046/j.1365-2265.1999.00816.x)

34 Boekholdt SM, Titan SM, Wiersinga WM, Chatterjee K, Basart DC, Luben R, Wareham NJ \& Khaw KT. Initial thyroid status and cardiovascular risk factors: the EPIC-Norfolk prospective 
population study. Clinical Endocrinology 201072 404-410. (doi:10.1111/j.1365-2265.2009.03640.x)

35 Sundbeck G, Eden S, Jagenburg R \& Lindstedt G. Thyroid dysfunction in 85-year-old men and women. Influence of nonthyroidal illness and drug treatment. Acta Endocrinologica 1991 125 475-486. (doi:10.1530/acta.0.1250475)

36 Hollowell JG, Staehling NW, Flanders WD, Hannon WH, Gunter EW, Spencer CA \& Braverman LE. Serum TSH, T(4), and thyroid antibodies in the United States population (1988 to 1994): National Health and Nutrition Examination Survey (NHANES III). Journal of Clinical Endocrinology and Metabolism 200287 489-499. (doi:10.1210/jcem.87.2.8182)

37 Selmer C, Olesen JB, Hansen ML, Lindhardsen J, Olsen AM, Madsen JC, Faber J, Hansen PR, Pedersen OD, Torp-Pedersen $\mathrm{C}$ et al. The spectrum of thyroid disease and risk of new onset atrial fibrillation: a large population cohort study. BMJ $2012 \mathbf{3 4 5}$ e7895. (doi:10.1136/bmj.e7895)

38 Cappola AR, Fried LP, Arnold AM, Danese MD, Kuller LH, Burke GL, Tracy RP \& Ladenson PW. Thyroid status, cardiovascular risk, and mortality in older adults. JAMA 2006295 1033-1041. (doi:10.1001/jama.295.9.1033)

39 Brochmann H, Bjoro T, Gaarder PI, Hanson F \& Frey HM. Prevalence of thyroid dysfunction in elderly subjects. A randomized study in a Norwegian rural community (Naeroy). Acta Endocrinologica 1988117 7-12.

40 Nanchen D, Gussekloo J, Westendorp RG, Stott DJ, Jukema JW, Trompet S, Ford I, Welsh P, Sattar N, Macfarlane PW et al. Subclinical thyroid dysfunction and the risk of heart failure in older persons at high cardiovascular risk. Journal of Clinical Endocrinology and Metabolism 201297 852-861. (doi:10.1210/ jc.2011-1978)

41 Meyerovitch J, Rotman-Pikielny P, Sherf M, Battat E, Levy Y \& Surks MI. Serum thyrotropin measurements in the community: five-year follow-up in a large network of primary care physicians. Archives of Internal Medicine 2007167 1533-1538. (doi:10.1001/ archinte.167.14.1533)

42 Canaris GJ, Manowitz NR, Mayor G \& Ridgway EC. The Colorado thyroid disease prevalence study. Archives of Internal Medicine 2000 160 526-534. (doi:10.1001/archinte.160.4.526)

43 Bjoro T, Holmen J, Kruger O, Midthjell K, Hunstad K, Schreiner T, Sandnes L \& Brochmann H. Prevalence of thyroid disease, thyroid dysfunction and thyroid peroxidase antibodies in a large, unselected population. The Health Study of Nord-Trondelag (HUNT). European Journal of Endocrinology 2000143 639-647. (doi:10.1530/eje.0.1430639)

44 Konno N, Yuri K, Taguchi H, Miura K, Taguchi S, Hagiwara $\mathrm{K} \&$ Murakami S. Screening for thyroid diseases in an iodine sufficient area with sensitive thyrotrophin assays, and serum thyroid autoantibody and urinary iodide determinations. Clinical Endocrinology 199338 273-281. (doi:10.1111/j.1365-2265.1993. tb01006.x)

45 Sundbeck G, Lundberg PA, Lindstedt G, Jagenburg R \& Eden S. Incidence and prevalence of thyroid disease in elderly women: results from the longitudinal population study of elderly people in Gothenburg, Sweden. Age Ageing 199120 291-298. (doi:10.1093/ageing/20.4.291)

46 Cooper DS \& Biondi B. Subclinical thyroid disease. Lancet 2012 379 1142-1154. (doi:10.1016/S0140-6736(11)60276-6)

47 Carle A, Pedersen IB, Knudsen N, Perrild H, Ovesen L, Rasmussen LB \& Laurberg P. Epidemiology of subtypes of hyperthyroidism in Denmark: a population-based study. European Journal of Endocrinology 2011164 801-809. (doi:10.1530/EJE-10-1155)

48 Laurberg P, Bulow P, I, Knudsen N, Ovesen L \& Andersen S. Environmental iodine intake affects the type of nonmalignant thyroid disease. Thyroid 200111 457-469. (doi:10.1089/10507250 1300176417)
49 Andersen S, Iversen F, Terpling S, Pedersen KM, Gustenhoff P \& Laurberg P. More hypothyroidism and less hyperthyroidism with sufficient iodine nutrition compared to mild iodine deficiency - a comparative population-based study of older people. Maturitas 200964 126-131. (doi:10.1016/j.maturitas.2009.08.007)

50 Vejbjerg P, Knudsen N, Perrild H, Laurberg P, Carle A, Pedersen IB, Rasmussen LB, Ovesen L \& Jorgensen T. Lower prevalence of mild hyperthyroidism related to a higher iodine intake in the population: prospective study of a mandatory iodization programme. Clinical Endocrinology 200971 440-445. (doi:10.1111/j.1365-2265.2008.03493.x)

51 Laurberg P, Cerqueira C, Ovesen L, Rasmussen LB, Perrild H, Andersen S, Pedersen IB \& Carle A. Iodine intake as a determinant of thyroid disorders in populations. Best Practice \& Research: Clinical Endocrinology \& Metabolism 201024 13-27.

52 Laurberg P, Pedersen KM, Hreidarsson A, Sigfusson N, Iversen E \& Knudsen PR. Iodine intake and the pattern of thyroid disorders: a comparative epidemiological study of thyroid abnormalities in the elderly in Iceland and in Jutland, Denmark. Journal of Clinical Endocrinology and Metabolism 199883 765-769. (doi:10.1210/ jcem.83.3.4624)

53 Carle A, Krejbjerg A \& Laurberg P. Epidemiology of nodular goitre. Influence of iodine intake. Best Best Practice \& Research: Clinical Endocrinology \& Metabolism 201428 465-479. (doi:10.1016/j. beem.2014.01.001)

54 Van de V, Netea-Maier R, Smit J, Kusters R, Van der SJ, PronkAdmiraal C, Buijs M, Schoenmakers C, Koehorst S, de Groot $\mathrm{M}$ et al. TSH versus age relationship as an indicator of historical iodine intake. Thyroid 201524 629-634.

55 Belin RM, Astor BC, Powe NR \& Ladenson PW. Smoke exposure is associated with a lower prevalence of serum thyroid autoantibodies and thyrotropin concentration elevation and a higher prevalence of mild thyrotropin concentration suppression in the third National Health and Nutrition Examination Survey (NHANES III). Journal of Clinical Endocrinology and Metabolism 200489 6077-6086. (doi:10.1210/jc.2004-0431)

56 Ericsson UB \& Lindgarde F. Effects of cigarette smoking on thyroid function and the prevalence of goitre, thyrotoxicosis and autoimmune thyroiditis. Journal of Internal Medicine 1991229 67-71. (doi:10.1111/j.1365-2796.1991.tb00308.x)

57 Rosario PW. Natural history of subclinical hyperthyroidism in elderly patients with TSH between 0.1 and $0.4 \mathrm{mIU} / \mathrm{l}: \mathrm{a}$ prospective study. Clinical Endocrinology 201072 685-688. (doi:10.1111/j.1365-2265.2009.03696.x)

58 Woeber KA. Observations concerning the natural history of subclinical hyperthyroidism. Thyroid 200515 687-691. (doi:10.1089/thy.2005.15.687)

59 Stott DJ, McLellan AR, Finlayson J, Chu P \& Alexander WD. Elderly patients with suppressed serum TSH but normal free thyroid hormone levels usually have mild thyroid overactivity and are at increased risk of developing overt hyperthyroidism. Quarterly journal of medicine 199178 77-84.

60 Diez JJ \& Iglesias P. An analysis of the natural course of subclinical hyperthyroidism. American Journal of the Medical Sciences 2009 337 225-232. (doi:10.1097/MAJ.0b013e318187e16d)

61 Schouten BJ, Brownlie BE, Frampton CM \& Turner JG. Subclinical thyrotoxicosis in an outpatient population - predictors of outcome. Clinical Endocrinology 201174 257-261. (doi:10.1111/ j.1365-2265.2010.03908.x)

62 Tenerz A, Forberg R \& Jansson R. Is a more active attitude warranted in patients with subclinical thyrotoxicosis? Journal of Internal Medicine 1990228 229-233. (doi:10.1111/j.1365-2796.1990.tb00223.x)

63 Vadiveloo T, Donnan PT, Cochrane L \& Leese GP. The Thyroid Epidemiology, Audit, and Research Study (TEARS): the natural history of endogenous subclinical hyperthyroidism. Journal 
of Clinical Endocrinology and Metabolism 201196 E1-E8. (doi:10.1210/jc.2010-0854)

64 Das G, Ojewuyi TA, Baglioni P, Geen J, Premawardhana LD \& Okosieme OE. Serum thyrotrophin at baseline predicts the natural course of subclinical hyperthyroidism. Clinical Endocrinology 2012 77 146-151. (doi:10.1111/j.1365-2265.2012.04345.x)

65 Karmisholt J, Andersen S \& Laurberg P. Interval between tests and thyroxine estimation method influence outcome of monitoring of subclinical hypothyroidism. Journal of Clinical Endocrinology and Metabolism 200893 1634-1640. (doi:10.1210/jc.2008-0101)

66 Biondi B, Palmieri EA, Fazio S, Cosco C, Nocera M, Sacca L, Filetti S, Lombardi G \& Perticone F. Endogenous subclinical hyperthyroidism affects quality of life and cardiac morphology and function in young and middle-aged patients. Journal of Clinical Endocrinology and Metabolism 200085 4701-4705. (doi:10.1210/jc.85.12.4701)

67 Auer J, Scheibner P, Mische T, Langsteger W, Eber O \& Eber B. Subclinical hyperthyroidism as a risk factor for atrial fibrillation. American Heart Journal 2001142 838-842. (doi:10.1067/ mhj.2001.119370)

68 Collet TH, Gussekloo J, Bauer DC, den Elzen WP, Cappola AR, Balmer P, Iervasi G, Asvold BO, Sgarbi JA, Volzke H et al. Subclinical hyperthyroidism and the risk of coronary heart disease and mortality. Archives of Internal Medicine 2012172 799-809.

69 Vadiveloo T, Donnan PT, Cochrane L \& Leese GP. The Thyroid Epidemiology, Audit, and Research Study (TEARS): morbidity in patients with endogenous subclinical hyperthyroidism. Journal of Clinical Endocrinology and Metabolism 201196 1344-1351. (doi:10.1210/jc.2010-2693)

70 Gencer B, Collet TH, Virgini V, Bauer DC, Gussekloo J, Cappola AR, Nanchen D, den Elzen WP, Balmer P, Luben RN et al. Subclinical thyroid dysfunction and the risk of heart failure events: an individual participant data analysis from 6 prospective cohorts. Circulation 2012126 1040-1049. (doi:10.1161/ CIRCULATIONAHA.112.096024)

71 Erem C. Blood coagulation, fibrinolytic activity and lipid profile in subclinical thyroid disease: subclinical hyperthyroidism increases plasma factor X activity. Clinical Endocrinology $2006 \mathbf{6 4}$ 323-329. (doi:10.1111/j.1365-2265.2006.02464.x)

72 Squizzato A, Gerdes VE, Brandjes DP, Buller HR \& Stam J. Thyroid diseases and cerebrovascular disease. Stroke 200536 2302-2310. (doi:10.1161/01.STR.0000181772.78492.07)

73 Dorr M, Empen K, Robinson DM, Wallaschofski H, Felix SB \& Volzke $\mathrm{H}$. The association of thyroid function with carotid artery plaque burden and strokes in a population-based sample from a previously iodine-deficient area. European Journal of Endocrinology 2008159 145-152. (doi:10.1530/EJE-08-0140)

74 Schultz M, Kistorp C, Raymond I, Dimsits J, Tuxen C, Hildebrandt P \& Faber J. Cardiovascular events in thyroid disease: a population based, prospective study. Hormone and Metabolic Research 201143 653-659. (doi:10.1055/s-0031-1283162)

75 Iervasi G, Molinaro S, Landi P, Taddei MC, Galli E, Mariani F, L'Abbate A \& Pingitore A. Association between increased mortality and mild thyroid dysfunction in cardiac patients. Archives of Internal Medicine 2007167 1526-1532. (doi:10.1001/ archinte.167.14.1526)

76 Selmer C, Olesen JB, Hansen ML, von Kappelgaard LM, Madsen JC, Hansen PR, Pedersen OD, Faber J, Torp-Pedersen C \& Gislason GH. Subclinical and overt thyroid dysfunction and risk of allcause mortality and cardiovascular events: a large population study. Journal of Clinical Endocrinology and Metabolism 201499 2372-2382. (doi:10.1210/jc.2013-4184)

77 Foldes J, Tarjan G, Szathmari M, Varga F, Krasznai I \& Horvath C. Bone mineral density in patients with endogenous subclinical hyperthyroidism: is this thyroid status a risk factor for osteoporosis? Clinical Endocrinology 199339 521-527. (doi:10.1111/j.1365-2265.1993.tb02403.x)

78 Mudde AH, Houben AJ \& Nieuwenhuijzen Kruseman AC. Bone metabolism during anti-thyroid drug treatment of endogenous subclinical hyperthyroidism. Clinical Endocrinology $1994 \mathbf{4 1}$ 421-424. (doi:10.1111/j.1365-2265.1994.tb02571.x)

79 Gurlek A \& Gedik O. Effect of endogenous subclinical hyperthyroidism on bone metabolism and bone mineral density in premenopausal women. Thyroid 1999 9 539-543. (doi:10.1089/ thy.1999.9.539)

80 Grimnes G, Emaus N, Joakimsen RM, Figenschau Y \& Jorde R. The relationship between serum TSH and bone mineral density in men and postmenopausal women: the Tromso study. Thyroid 200818 1147-1155. (doi:10.1089/thy.2008.0158)

81 Tauchmanova L, Nuzzo V, Del Puente A, Fonderico F, Esposito-Del Puente A, Padulla S, Rossi A, Bifulco G, Lupoli G \& Lombardi G. Reduced bone mass detected by bone quantitative ultrasonometry and DEXA in pre- and postmenopausal women with endogenous subclinical hyperthyroidism. Maturitas 200448 299-306. (doi:10.1016/j.maturitas.2004.02.017)

82 Garin MC, Arnold AM, Lee JS, Robbins J \& Cappola AR. Subclinical thyroid dysfunction and hip fracture and bone mineral density in older adults: the cardiovascular health study. Journal of Clinical Endocrinology and Metabolism 201499 2657-2664. (doi:10.1210/jc.2014-1051)

83 Lee JS, Buzkova P, Fink HA, Vu J, Carbone L, Chen Z, Cauley J, Bauer DC, Cappola AR \& Robbins J. Subclinical thyroid dysfunction and incident hip fracture in older adults. Archives of Internal Medicine Journal 2010170 1876-1883.

84 Leader A, Ayzenfeld RH, Lishner M, Cohen E, Segev D \& Hermoni D. Thyrotropin levels within the lower normal range are associated with an increased risk of hip fractures in euthyroid women, but not men, over the age of 65 years. Journal of Clinical Endocrinology and Metabolism 201499 2665-2673. (doi:10.1210/ jc.2013-2474)

85 Wirth CD, Blum MR, da Costa BR, Baumgartner C, Collet TH, Medici M, Peeters RP, Aujesky D, Bauer DC \& Rodondi N. Subclinical thyroid dysfunction and the risk for fractures: a systematic review and meta-analysis. Annals of Internal Medicine 2014161 189-199. (doi:10.7326/M14-0125)

86 Blum MR, Bauer DC, Collet TH, Fink HA, Cappola AR, da Costa BR, Wirth CD, Peeters RP, Asvold BO, den Elzen WP et al. Subclinical thyroid dysfunction and fracture risk: a meta-analysis. JAMA 2015313 2055-2065. (doi:10.1001/jama.2015.5161)

87 Volzke H, Schwahn C, Wallaschofski H \& Dorr M. Review: the association of thyroid dysfunction with all-cause and circulatory mortality: is there a causal relationship? Journal of Clinical Endocrinology and Metabolism 200792 2421-2429. (doi:10.1210/ jc.2007-0179)

88 Haentjens P, Van Meerhaeghe A, Poppe K \& Velkeniers B. Subclinical thyroid dysfunction and mortality: an estimate of relative and absolute excess all-cause mortality based on time-toevent data from cohort studies. European Journal of Endocrinology 2008159 329-341. (doi:10.1530/EJE-08-0110)

89 Collet TH, Gussekloo J, Bauer DC, den Elzen WP, Cappola AR, Balmer P, Iervasi G, Asvold BO, Sgarbi JA, Volzke H et al. Subclinical hyperthyroidism and the risk of coronary heart disease and mortality. Archives of Internal Medicine 2012.

90 Welch KC \& McHenry CR. Total thyroidectomy: is morbidity higher for Graves' disease than nontoxic goiter? Journal of Surgical Research 2011170 96-99. (doi:10.1016/j. jss.2011.03.054)

91 Codaccioni JL, Orgiazzi J, Blanc P, Pugeat M, Roulier R \& Carayon P. Lasting remissions in patients treated for Graves' hyperthyroidism with propranolol alone: a pattern of spontaneous 
evolution of the disease. Journal of Clinical Endocrinology and Metabolism 198867 656-662. (doi:10.1210/jcem-67-4-656)

92 Abraham P, Avenell A, McGeoch SC, Clark LF \& Bevan JS. Antithyroid drug regimen for treating Graves' hyperthyroidism. Cochrane Database of Systematic Reviews 2010 CD003420.

93 Carle A, Knudsen N, Pedersen IB, Perrild H, Ovesen L, Rasmussen LB \& Laurberg P. Determinants of serum T4 and T3 at the time of diagnosis in nosological types of thyrotoxicosis: a populationbased study. European Journal of Endocrinology 2013169 537-545. (doi:10.1530/EJE-13-0533)

94 Pallais JC, McInnis M, Saylor PJ \& Wu RI. Case records of the Massachusetts General Hospital. Case 38-2015. A 21-year-old man with fatigue and weight loss. New England Journal of Medicine 2015373 2358-2369. (doi:10.1056/NEJMcpc1506821)

95 Bonnema SJ \& Hegedus L. Radioiodine therapy in benign thyroid diseases: effects, side effects, and factors affecting therapeutic outcome. Endocrine Reviews 201233 920-980. (doi:10.1210/ er.2012-1030)

96 Bonnema SJ, Bertelsen H, Mortensen J, Andersen PB, Knudsen DU, Bastholt L \& Hegedus L. The feasibility of high dose iodine 131 treatment as an alternative to surgery in patients with a very large goiter: effect on thyroid function and size and pulmonary function. Journal of Clinical Endocrinology and Metabolism $1999 \mathbf{8 4}$ 3636-3641. (doi:10.1210/jc.84.10.3636)

97 Hegedus L, Hansen BM, Knudsen N \& Hansen JM. Reduction of size of thyroid with radioactive iodine in multinodular non-toxic goitre. BMJ 1988297 661-662. (doi:10.1136/bmj.297.6649.661)

98 Verelst J, Bonnyns M \& Glinoer D. Radioiodine therapy in voluminous multinodular non-toxic goitre. Acta Endocrinologica 1990122 417-421. (doi:10.1530/acta.0.1220417)

99 Wesche MF, Buul MM, Smits NJ \& Wiersinga WM. Reduction in goiter size by 131I therapy in patients with non-toxic multinodular goiter. European Journal of Endocrinology 1995132 86-87. (doi:10.1530/eje.0.1320086)

100 Nygaard B, Hegedus L, Gervil M, Hjalgrim H, Soe-Jensen P \& Hansen JM. Radioiodine treatment of multinodular non-toxic goitre. BMJ 1993307 828-832. (doi:10.1136/bmj.307.6908.828)

101 Paschke R, Niedziela M, Vaidya B, Persani L, Rapoport B \& Leclere J. 2012 European thyroid association guidelines for the management of familial and persistent sporadic non-autoimmune hyperthyroidism caused by thyroid-stimulating hormone receptor germline mutations. European Thyroid Journal 20121 142-147. (doi:10.1159/000342982)

102 Rodien P, Bremont C, Sanson ML, Parma J, van Sande J, Costagliola S, Luton JP, Vassart G \& Duprez L. Familial gestational hyperthyroidism caused by a mutant thyrotropin receptor hypersensitive to human chorionic gonadotropin. New England Journal of Medicine 1998339 1823-1826. (doi:10.1056/ NEJM199812173392505)

103 Bahre M, Hilgers R, Lindemann C \& Emrich D. Thyroid autonomy: sensitive detection in vivo and estimation of its functional relevance using quantified high-resolution scintigraphy. Acta Endocrinologica 1988117 145-153. (doi:10.1530/acta.0.1170145)

104 Faber J, Jensen IW, Petersen L, Nygaard B, Hegedus L \& SiersbaekNielsen K. Normalization of serum thyrotrophin by means of radioiodine treatment in subclinical hyperthyroidism: effect on bone loss in postmenopausal women. Clinical Endocrinology 1998 48 285-290. (doi:10.1046/j.1365-2265.1998.00427.x)

105 Rosario PW. Radioiodine therapy in elderly patients with subclinical hyperthyroidism due to non-voluminous nodular goiter and its effect on bone metabolism. Arquivos Brasileiros de Endocrinologia and Metabologia 201357 144-147. (doi:10.1590/ S0004-27302013000200008)

106 Faber J, Wiinberg N, Schifter S \& Mehlsen J. Haemodynamic changes following treatment of subclinical and overt hyperthyroidism. European Journal of Endocrinology 2001145 391-396. (doi:10.1530/eje.0.1450391)

107 Ceccarelli C, Bencivelli W, Vitti P, Grasso L \& Pinchera A. Outcome of radioiodine-131 therapy in hyperfunctioning thyroid nodules: a 20 years' retrospective study. Clinical Endocrinology 200562 331-335. (doi:10.1111/j.1365-2265.2005.02218.x)

108 Holm LE, Lundell G, Israelsson A \& Dahlqvist I. Incidence of hypothyroidism occurring long after iodine-131 therapy for hyperthyroidism. Journal of Nuclear Medicine 198223 103-107.

109 Yano Y, Sugino K, Akaishi J, Uruno T, Okuwa K, Shibuya H, Kitagawa W, Nagahama M, Ito K \& Ito K. Treatment of autonomously functioning thyroid nodules at a single institution: radioiodine therapy, surgery, and ethanol injection therapy. Annals of Nuclear Medicine 201125 749-754. (doi:10.1007/s12149011-0526-7)

110 Tajiri J. Radioiodine treatment of patients with autonomously functioning thyroid nodules at outpatient clinic. Kaku Igaku 2006 43 75-83.

111 Laurberg P, Wallin G, Tallstedt L, Abraham-Nordling M, Lundell G \& Torring O. TSH-receptor autoimmunity in Graves' disease after therapy with anti-thyroid drugs, surgery, or radioiodine: a 5-year prospective randomized study. European Journal of Endocrinology 2008158 69-75. (doi:10.1530/eje-07-0450)

112 Hall P, Lundell G \& Holm LE. Mortality in patients treated for hyperthyroidism with iodine-131. Acta Endocrinologica 1993128 230-234. (doi:10.1530/acta.0.1280230)

113 Franklyn JA, Maisonneuve P, Sheppard MC, Betteridge J \& Boyle P. Mortality after the treatment of hyperthyroidism with radioactive iodine. New England Journal of Medicine 1998338 712-718. (doi:10.1056/NEJM199803123381103)

114 Franklyn JA, Sheppard MC \& Maisonneuve P. Thyroid function and mortality in patients treated for hyperthyroidism. JAMA 2005 294 71-80. (doi:10.1001/jama.294.1.71)

115 Metso S, Jaatinen P, Huhtala H, Auvinen A, Oksala H \& Salmi J. Increased cardiovascular and cancer mortality after radioiodine treatment for hyperthyroidism. Journal of Clinical Endocrinology and Metabolism 200792 2190-2196. (doi:10.1210/jc.20062321)

116 Boelaert K, Maisonneuve P, Torlinska B \& Franklyn JA. Comparison of mortality in hyperthyroidism during periods of treatment with thionamides and after radioiodine. Journal of Clinical Endocrinology and Metabolism 201398 1869-1882. (doi:10.1210/jc.2012-3459)

117 Sisson JC, Freitas J, McDougall IR, Dauer LT, Hurley JR, Brierley JD, Edinboro CH, Rosenthal D, Thomas MJ, Wexler JA et al. Radiation safety in the treatment of patients with thyroid diseases by radioiodine 131I: practice recommendations of the American Thyroid Association. Thyroid 201121 335-346. (doi:10.1089/ thy.2010.0403)

118 Cooper DS. Antithyroid drugs. New England Journal of Medicine 2005352 905-917. (doi:10.1056/NEJMra042972)

119 Bartalena L, Bogazzi F \& Martino E. Adverse effects of thyroid hormone preparations and antithyroid drugs. Drug Safety 199615 53-63. (doi:10.2165/00002018-199615010-00004)

120 Watanabe N, Narimatsu H, Noh JY, Yamaguchi T, Kobayashi K, Kami M, Kunii Y, Mukasa K, Ito K \& Ito K. Antithyroid druginduced hematopoietic damage: a retrospective cohort study of agranulocytosis and pancytopenia involving 50,385 patients with Graves' disease. Journal of Clinical Endocrinology and Metabolism 201297 E49-E53. (doi:10.1210/jc.2011-2221)

121 Nakamura H, Miyauchi A, Miyawaki N \& Imagawa J. Analysis of 754 cases of antithyroid drug-induced agranulocytosis over 30 years in Japan. Journal of Clinical Endocrinology and Metabolism 201398 4776-4783. (doi:10.1210/jc.2013-2569)

122 Andersen SL, Olsen J \& Laurberg P. Antithyroid drug side effects in the population and in pregnancy. Journal of Clinical Endocrinology 
and Metabolism 2016101 1606-1614 jc20154274. (doi:10.1210/ jc.2015-4274)

123 Yoshihara A, Noh JY, Watanabe N, Mukasa K, Ohye H, Suzuki M, Matsumoto M, Kunii Y, Suzuki N, Kameda T et al. Substituting potassium iodide for methimazole as the treatment for Graves' disease during the first trimester may reduce the incidence of congenital anomalies: a retrospective study at a single medical institution in Japan. Thyroid 201525 1155-1161. (doi:10.1089/ thy.2014.0581)

124 Andersen SL, Olsen J, Wu CS \& Laurberg P. Birth defects after early pregnancy use of antithyroid drugs: a Danish Nationwide study. Journal of Clinical Endocrinology and Metabolism 201398 4373-4381. (doi:10.1210/jc.2013-2831)

125 Andersen SL, Olsen J, Wu CS \& Laurberg P. Severity of birth defects after propylthiouracil exposure in early pregnancy. Thyroid 201424 1533-1540. (doi:10.1089/thy.2014.0150)

126 Laurberg P \& Andersen SL. Antithyroid drug use in pregnancy and birth defects: why some studies find clear associations, and some studies report none. Thyroid 201525 1185-1190. (doi:10.1089/ thy.2015.0182)
Laurberg P \& Andersen SL. Graves'-Basedow disease in pregnancy. New trends in the management and guidance to reduce the risk of birth defects caused by antithyroid drugs. Nuklearmedizin $2015 \mathbf{5 4}$ 106-111.

128 Laurberg P, Andersen SL, Hindersson P, Nohr EA \& Olsen J. Dynamics and predictors of serum TSH and fT4 reference limits in early pregnancy. A study within the Danish national birth cohort. Journal of Clinical Endocrinology and Metabolism 2016101 2484-2492 jc20161387. (doi:10.1210/jc.2016-1387)

129 Casey BM, Dashe JS, Wells CE, McIntire DD, Leveno KJ \& Cunningham FG. Subclinical hyperthyroidism and pregnancy outcomes. Obstetrics and Gynecology 2006107 337-341. (doi:10.1097/01.AOG.0000197991.64246.9a)

130 Bahn RS, Burch HB, Cooper DS, Garber JR, Greenlee MC, Klein I, Laurberg P, McDougall IR, Montori VM, Rivkees SA et al. Hyperthyroidism and other causes of thyrotoxicosis: management guidelines of the American Thyroid Association and American Association of Clinical Endocrinologists. Endocrine Practice 201117 456-520. (doi:10.4158/EP.17.3.456)

Received 27 March 2016

Revised version received 23 December 2016

Accepted 8 March 2017 